\title{
Investigation of DNAmethylation of TWIST Gene in Breast Cancer and Its Relationship to Histopathological Features
}

\author{
Onur Eroglu ${ }^{1,2^{*}}\left(\mathbb{D}\right.$, Oguz Cilingir ${ }^{3}$, Sevilhan Artan ${ }^{3}$, Beyhan Durak Aras ${ }^{3}$ \\ ${ }^{1}$ Department of Molecular Biology and Genetics, Faculty of Science and Letters, Bilecik Seyh Edebali University, Bilecik, Turkey \\ ${ }^{2}$ Biotechnology Research and Application Center, Bilecik Seyh Edebali University, Bilecik, Turkey \\ ${ }^{3}$ Department of Medical Genetics, Faculty of Medicine, Osmangazi University, Eskisehir, Turkey \\ Email: *onur.eroglu@bilecik.edu.tr
}

How to cite this paper: Eroglu, O., Cilingir, O., Artan, S. and Aras, B.D. (2019) Investigation of DNAmethylation of TWIST Gene in Breast Cancer and Its Relationship to Histopathological Features. Advances in Breast Cancer Research, 8, 45-59. https://doi.org/10.4236/abcr.2019.81004

Received: December 24, 2018

Accepted: January 20, 2019

Published: January 23, 2019

Copyright $\odot 2019$ by author(s) and Scientific Research Publishing Inc. This work is licensed under the Creative Commons Attribution International License (CC BY 4.0).

http://creativecommons.org/licenses/by/4.0/

\begin{abstract}
BACKGROUND: Promoter hypermethylation and global hypomethylation in the human genome are hallmarks of most cancers. OBJECTIVE: The aim of this study is to assess the methylation profile patterns of TWIST gene and to investigate the relationship of methylation with pathological features. METHODS: Romoter CpGisland methylation of TWIST which can be related in breast cancer was performed by methylation-sensitive high resolution melting (MS-HRM) analysis. Formalin-fixed, paraffin-embedded (FFPE) tissue samples of 80 patients with a diagnosis of primary breast cancer from Eskisehir Osmangazi University medical faculty of Oncology Clinic were included. RESULTS: In our study, the promoter hypermethylation frequency of TWIST gene was $25.0 \%$. With these results, when the prognostic factors of the patients were analyzed, tumor stage and age were found to be meaningless with the hypermethylation of TWIST gene, but found to be significant with lymph node positivity, ER positivity, PR negativity, and HER2/NEU negativity. CONCLUSION: Our study is important as being the first study that analyzes association between histopathologic type and TWIST gene promotor methylation status in Turkish population.
\end{abstract}

\section{Keywords}

Breast Cancer, Methylation, MS-HRM, TWIST

\section{Introduction}

Hypermethylation is an epigenetic change that blocks the promoter region of a gene and results in gene silencing [1]. In breast cancer, tumor-related genes may 
be silenced by hypermethylation; many hypermethylated genes have been reported, and silencing of these genes plays important roles in carcinogenesis and tumor progression [2] [3] [4] [5]. Identification of epigenetic changes and their correlation with other clinical factors could lead to improvements in cancer diagnosis and treatment.

Human basic helix-loop-helix DNA binding protein (TWIST; location: 7p21.2; GenBank: U80998) induces E-cadherin mediated cell-cell adhesion and induction of cell motility. Increased expression of TWIST correlates with tumor invasion and metastasis [6].

DNA methylation is the epigenetic change, which has been mostly reported to be associated with TWIST and interfere with Twist expression. Usually, hypermethylation of the promoter region of TWIST gene has been known in certain cancers of breast, uterine cervix, ovary, bladder, colorectal, gastric, lung, bone and brain [7]. For the detection of cancer cells and cancer typing in biological samples, the tumor specific promoter hypermethylation of TWIST is becoming a promising tool. However, it is not very clear how the TWIST promoter hypermethylation is responsible for carcinogenesis. Evidences showed that the increased frequency of hypermethylated genes in distant metastasis might be an important event in cancer progression. It has been reported that the hypermethylated TWIST gene is more frequently found in the local and distant metastasis than in primary breast carcinomas [8]. To clarify the epigenetic mechanism of Twist, Gort [9] proposed two possibilities: [10] the proximal part of the TWIST promoter is not related to TWIST expression, rather than interfering with other genes in genomic proximity like HDAC9 and FERD3L; [7] hypermethylation of TWIST promoter might be an early event that precedes compensatory TWIST over-expression [11]. Chromatin remodeling is another important epigenetic change of Twist responsible for cancer. Evidence showed that a protein complex formed by Twist with the Mi2/nucleosome remodeling and deacetylase, termed as Twist/Mi2/NuRD, plays an essential role in invasive and metastatic cancer cells [12]. miR-10b has also been reported to target Twist but change of miR-10b expression alone can't induce breast cancer cell into EMT [13], and other factors might be associated. However, these mechanisms are not enough to understand the epigenetics of Twist in cancer clearly, and a vast things to know. In cancer therapeutics, controlling metastasis remains one of the mainstream focuses, and targeting Twist might be the new dimension in controlling metastatic cancers. Several attempts have been taken to manipulate Twist function in cancer cells, including epigenetic approaches. Particularly, in hormone resistant breast cancer, epigenetic modification of Twist is able to restore hormone sensitivity, as Twist can serve as a potential target for converting estrogen receptor (ER)- $\alpha$-negative breast cancers to ER- $\alpha$-positive breast cancers [14] [15]. Exploring Twist epigenetics might be a very interesting topic for the cancer researchers for the invention of new therapeutic approach for cancer treatment. 
The aim of this study is to find out the frequency and the level of methylation of TWIST gene in breast cancer to determine whether the methylated gene is associated with histopathological parameters. We have assessed whether DNA methylation profiling may be used clinically to distinguish the early diagnosis of cancer, tumor classification, prognosis and the regulation of treatment protocols.

\section{Materials and Methods}

\subsection{Sample Collection and DNA Preparation}

This study was conducted between 2009-2011. Formalin-fixed, paraffin-embedded samples from 80 primary breast tumors tissue samples were collected from Eskisehir Osmangazi University medical faculty of Oncology Clinic were included. Samples which were embedded in parafin tissue blocks as 10 sections of 10 microns thick and in eppendorf tubes were taken from Eskisehir Osmangazi University of medical faculty of Pathology department. Pathologists decided the sample size.All tumor specimens have at least $70 \%$ of tumorous tissue. Besides the TWIST methylation, the histopathlogical parameters such as age, tumor stage, tumor type, lymph node metastasis, estrogen receptor, progesterone receptor and Her2/neu status were collected from and related with the methylation levels. After deparafinization, genomic DNA was extracted using MagNA Pure Compact Nucleic Acid Isolation Kit I (Roche) according to the manufacturer's instructions.

\subsection{Bisulphite Modification and Methylation Analysis}

Approximately 250 - 500 nanogram of genomic DNA was bisulphite modified using the EpiTect Bisulphite kit (Qiagen) according to the manufacturer's instructions. The modified DNA was eluted three times in $50 \mu$ Elution Buffer (EB). Methylation analysis was performed using Methylation-sensitive high resolution melting (MS-HRM) in which the approximate level of methylation and presence of heterogeneous methylation can be determined in bisulphite modified DNA [4] [16] [17]. PCR amplification and high resolution melting analysis were performed on the Roche LightCycler 480 (Roche Applied Science, Laval, PQ, Canada) equipped with the Gene Scanning software (Version 1.5.0). MS-HRM primers and amplicon details are listed in Table 1. In order to detect the promoter methylation status of TWIST gene we used a real-time polymerase chain reaction (PCR) approach followed by high resolution melting curve analysis (HRM), considered as a rapid, highly sensitive and efficient method displaying the sequence-dependent melting profile of an amplicon. PCR and HRM analysis were consecutively performed on a LightCycler 480 (Roche Diagnostics GmbH, Germany) in one single run, and all samples were analysed in duplicate. Each reaction mixture contained $\sim 1-2 \mu \mathrm{l}$ of bisulfite-treated DNA, $200 \mathrm{nmol} / \mu \mathrm{l}$ of each primer, $10 \mu \mathrm{l}$ of LightCycler 480 High Resolution Melting Master (Roche), $3.5 \mathrm{mM} \mathrm{MgCl}_{2}$ and PCR-grade water adjusted to a total volume of $20 \mu$ l. The conditions used in the Light Cycler 480 were an initial cycle at $95^{\circ} \mathrm{C}$ 
for $10 \mathrm{~min}$, followed by 50 cycles of $95^{\circ} \mathrm{C}$ for $1 \mathrm{~min}$, followed by annealing at $40^{\circ} \mathrm{C}$ for $1 \mathrm{~min}$. Samples were quickly warmed to $65^{\circ} \mathrm{C}$ and then slowly warmed to $95^{\circ} \mathrm{C}$ at $0.1^{\circ} \mathrm{C}$ per second. HRM was performed from $65^{\circ} \mathrm{C}$ to $95^{\circ} \mathrm{C}$ with a temperature increase at $0.10^{\circ} \mathrm{C} / \mathrm{sec}$ [18]. CpGenome TM Universal Methylated DNA (Chemicon/Millipore, Billerica, MA) and CpGenome Universal Unmethylated DNA were used as the fully methylated and unmethylated controls, respectively. Methylation standards (25\%, 50\%, 75\% and 100\%) made by diluting the fully methylated control in the unmethylated DNA were used as controls. Whole-genome amplification (WGA) was also used to make a fully unmethylated control and performed as described previously [19].

\subsection{Statistical Analysis}

The v2 test and binary logistic regression were used to analyse the relationship of methylation with the clinicopathological findings. The analyses were carried out with SPSS version 15.0 (SPSS Inc., Chicago, IL). A two tailed P-value of less than 0.05 was considered to be statistically significant for each comparison.

\section{Results}

\subsection{Patient Characteristics}

Patient characteristics included in this study are summarised in Table 2. Patients with primary breast tumors were aged between 32 and 83 (median $=58.44 \pm$ 11.09 ). Respectively $19 / 80$ cases of them (24\%) was $\leq 50$ years of age, $61 / 80$ 's in $(76 \%)>50$ years of age.

\subsection{Methylation Status in Primary Breast Tumor Samples}

A summary of the promoter methylation analysis of TWIST gene in 80 primary breast tumours are shown in Table 3 and Table 4 and examples of the MS-HRM results are shown in Figures 1-3. Mentioned gene showed detectable promoter methylation in primary breast tumours. TWIST1, was methylated in $25 \%$ of primary breast tumors.

\subsection{Correlation between DNA Methylation and Clinicopathological Parameters}

When the only methylated groups were compared, there is no correlation between the TWIST gene hypermethylation and tumor stage $(\mathrm{p}>0.05)$ and age $(p>0.05)$. TWIST gene hypermethylation was found to be significant with lymph node positivity $(\mathrm{p}<0.001)$, EstrogenReceptor $(\mathrm{ER})$ positivity $(\mathrm{p}<0.05)$, Progesterone Receptor (PR) negativity $(\mathrm{p}<0.05)$, and HER2/NEU negativity ( $\mathrm{p}$ $<0.05)$.

When we compare the hypermetylation of TWIST gene with the type of tumor, increased promoter methylation level have seen in invasive ductal carcinoma (IDC) then the invasive lobular carcinoma (ILC) tumor type ( $\mathrm{p}>$ $0.001)$. 
Table 1. Primer sequence of the gene.

\begin{tabular}{cc}
\hline Gene & Primer Sequence \\
\hline & Methylation forward; 5'-TTTCGGATGGGGTTGTTATCG-3' \\
TWIST & Methylation reverse; 5'-GACGAACGCGAAACGATTTC-3' \\
& Unmethylation forward; 5'-TTGGATGGGGTTGTTATTGT-3' \\
& Unmethylation reverse; 5'-ACCTTCCTCCAACAAACACA-3' \\
\hline
\end{tabular}

Table 2. Clinical characteristics ofpatients.

\begin{tabular}{|c|c|}
\hline The demographic characteristics & Number of patients \\
\hline \multicolumn{2}{|l|}{ AGE } \\
\hline$\leq 50 \mathrm{AGE}$ & 19 \\
\hline$>50 \mathrm{AGE}$ & 61 \\
\hline \multicolumn{2}{|l|}{ STAGE } \\
\hline STAGE II & 29 \\
\hline STAGE III & 45 \\
\hline STAGE IV & 6 \\
\hline \multicolumn{2}{|l|}{ THE TYPE OF TUMOR } \\
\hline INVASIVE DUCTAL CARCINOMA & 67 \\
\hline INVASIVE LOBULAR CARCINOMA & 13 \\
\hline \multicolumn{2}{|l|}{ LYMPHNODEMETASTASIS } \\
\hline POSITIVE & 67 \\
\hline NEGATIVE & 13 \\
\hline \multicolumn{2}{|l|}{ ESTROGENRECEPTOR (ER) } \\
\hline POSITIVE & 54 \\
\hline NEGATIVE & 26 \\
\hline \multicolumn{2}{|l|}{ PROGESTERONE RECEPTOR (PR) } \\
\hline POSITIVE & 42 \\
\hline NEGATIVE & 38 \\
\hline \multicolumn{2}{|l|}{ HER2/NEU } \\
\hline POSITIVE & 30 \\
\hline NEGATIVE & 50 \\
\hline
\end{tabular}

Table 3. Associations between gene promoter methylation and clinicopathological features of breast cancer.

\begin{tabular}{cll}
\hline Variables & TWIST methylation & \\
Patients & M UM \\
(n) $(\%)$ & $\mathrm{n}(\%) \mathrm{n}(\%)$ & \\
\hline Totally: 80 patients & $20(25) 60(75)$ & \\
Age & $8(42.1) 11(57.9)$ & $(\mathrm{p}>0.05)$ \\
$\leq 5019(24)$ & $12(19.7) 49(80.3)$ & \\
$>5061(76)$ & & \\
\hline
\end{tabular}




\section{Continued}

\begin{tabular}{cll}
\hline Stage & $3(10.3) 26(89.7)$ & \\
II 29 (37.5) & $14(31.1) 31(68.9)$ & $(\mathrm{p}>0.05)$ \\
III 45 (55) & $3(50) 3(50)$ & \\
IV 6 (7.5) & & \\
Type of Tumor & $16(23.9) 51(76.1)$ & $(\mathrm{p}>0.001)$ \\
IDC 67 (83.75) & $4(30.8) 9(69.2)$ & \\
ILC 13 (16.25) & & \\
Lymph Node & $17(25.4) 50(74.6)$ & $(\mathrm{p}<0.001)$ \\
Positive 67 (85) & $3(23.1) 10(76.9)$ & \\
Negative 13 (15) & & \\
Estrogen Receptor & $12(22.3) 42(77.7)$ & $(\mathrm{p}<0.05)$ \\
Positive54 (67.5) & $8(30.8) 18(69.2)$ & \\
Negative 26 (32.5) & & \\
Progesterone Receptor & $8(19) 34(81)$ & $(\mathrm{p}<0.05)$ \\
Positive 42 (52.5) & $12(31.6) 26(68.4)$ & \\
Negative 38 (47.5) & & $(\mathrm{p}<0.05)$ \\
HER2/NEU & $6(20) 24(80)$ & \\
Positive 30 (37.5) & $14(28) 36(72)$ & \\
Negative 50 (62.5) & & \\
& &
\end{tabular}

M: Methylation, UM: Unmethylation, n: Number of Patients.

Table 4. Methylation rates of TWIST gene and the prognostic factors of all cases.

\begin{tabular}{|c|c|c|c|c|c|c|c|c|}
\hline No & Age & Tumor Type & Stage & TNM Staging & ER & PR & HER2 & TWIST meth. \\
\hline 1 & 54 & Invasive ductal & $3 \mathrm{~A}$ & $\mathrm{~T} 2 \mathrm{~N} 2 \mathrm{M} 0$ & - & - & - & $<25$ \\
\hline 2 & 72 & Invasivelobular & $3 \mathrm{~A}$ & $\mathrm{~T} 2 \mathrm{~N} 2 \mathrm{M} 0$ & + & + & + & 25 \\
\hline 3 & 32 & Invasive ductal & $3 \mathrm{~A}$ & T2N1M0 & + & + & - & 25 \\
\hline 4 & 67 & Invasive ductal & $2 \mathrm{~B}$ & T2N1M0 & - & - & - & UN \\
\hline 5 & 47 & Infiltrative ductal & $2 \mathrm{~A}$ & T1N1M0 & - & + & - & UN \\
\hline 6 & 52 & Invasive ductal & $3 \mathrm{~A}$ & T3N2M0 & - & - & - & UN \\
\hline 7 & 54 & Invasive ductal & $3 \mathrm{~A}$ & T3N2M0 & - & - & - & UN \\
\hline 8 & 60 & Infiltrative ductal & $2 \mathrm{~B}$ & T2N1M0 & - & - & - & UN \\
\hline 9 & 64 & Invasive ductal & $2 \mathrm{~A}$ & T1N1M0 & - & - & + & UN \\
\hline 10 & 59 & Invasive ductal & $3 \mathrm{~B}$ & T4N2M0 & - & + & + & UN \\
\hline 11 & 70 & Invasive ductal & $3 \mathrm{~B}$ & T4N2M0 & + & + & - & UN \\
\hline 12 & 74 & Infiltrative ductal & $3 \mathrm{~A}$ & $\mathrm{~T} 2 \mathrm{~N} 2 \mathrm{MO}$ & + & + & - & UN \\
\hline 13 & 54 & Invasive ductal & $3 \mathrm{~B}$ & T2N3M0 & + & + & + & UN \\
\hline 14 & 45 & Invasive ductal & $3 \mathrm{~A}$ & T3N2M0 & + & + & + & UN \\
\hline 15 & 83 & Invasive ductal & $3 B$ & T2N2M0 & + & + & - & UN \\
\hline 16 & 47 & Invasive ductal & $3 \mathrm{~B}$ & T3N3M0 & + & - & - & $<25$ \\
\hline 17 & 51 & Invasive ductal & $3 \mathrm{~A}$ & T3N2M0 & - & - & + & UN \\
\hline 18 & 73 & Invasive ductal & $3 \mathrm{~A}$ & T3N2M0 & + & - & + & UN \\
\hline 19 & 43 & Infiltrativeductal & $3 \mathrm{~A}$ & $\mathrm{~T} 3 \mathrm{~N} 2 \mathrm{M} 0$ & + & + & + & UN \\
\hline 20 & 74 & Infiltrativeductal & $3 \mathrm{~A}$ & T3N2M0 & - & + & - & 50 \\
\hline
\end{tabular}




\section{Continued}

\begin{tabular}{|c|c|c|c|c|c|c|c|c|}
\hline 21 & 61 & Infiltrative ductal & $2 \mathrm{~B}$ & T2N1M0 & - & - & - & UN \\
\hline 22 & 71 & Invasive ductal & $2 \mathrm{~B}$ & T2N1M0 & + & + & + & UN \\
\hline 23 & 69 & Invasivelobular & $2 \mathrm{~B}$ & T2N1M0 & + & - & - & 25 \\
\hline 24 & 77 & Invasivelobular & $3 \mathrm{~A}$ & T1N2M0 & + & + & - & UN \\
\hline 25 & 51 & Invasive ductal & $2 \mathrm{~B}$ & T2N1M0 & - & - & - & 25 \\
\hline 26 & 69 & Infiltrative ductal & $2 \mathrm{~A}$ & T2N0M0 & + & - & - & UN \\
\hline 27 & 52 & Invasive ductal & $3 \mathrm{~A}$ & T3N2M0 & + & + & + & UN \\
\hline 28 & 66 & Infiltrative lobular & $2 \mathrm{~B}$ & T2N1M0 & + & - & + & UN \\
\hline 29 & 79 & Invasivelobular & $2 \mathrm{~A}$ & T1N1M0 & + & + & - & UN \\
\hline 30 & 52 & Invasive ductal & $3 \mathrm{~A}$ & T3N2M0 & + & + & + & UN \\
\hline 31 & 61 & Invasive ductal & $2 \mathrm{~B}$ & T2N1M0 & + & + & - & $\mathrm{UN}$ \\
\hline 32 & 50 & Infiltrative ductal & $3 \mathrm{~B}$ & T4N3M0 & + & - & - & 75 \\
\hline 33 & 48 & Invasivelobular & $2 \mathrm{~B}$ & T3N0M0 & + & + & + & UN \\
\hline 34 & 63 & Invasive ductal & 4 & T4N1M1 & + & - & + & UN \\
\hline 35 & 45 & Invasivelobular & $2 \mathrm{~A}$ & T1N1M0 & + & + & - & $\mathrm{UN}$ \\
\hline 36 & 66 & Infiltrative ductal & $2 \mathrm{~B}$ & T2N1M0 & + & - & - & $\mathrm{UN}$ \\
\hline 37 & 42 & Invasive ductal & $2 \mathrm{~B}$ & T2N1M0 & + & - & + & $\mathrm{UN}$ \\
\hline 38 & 72 & Infiltrative ductal & $2 \mathrm{~B}$ & T2N1M0 & + & + & - & UN \\
\hline 39 & 58 & Invasivelobular & $2 \mathrm{~A}$ & T1N1M0 & + & + & + & UN \\
\hline 40 & 52 & Invasivelobular & $2 \mathrm{~A}$ & T1N1M0 & + & + & + & UN \\
\hline 41 & 63 & Invasive ductal & $2 \mathrm{~B}$ & T3N0M0 & - & - & - & $\mathrm{UN}$ \\
\hline 42 & 75 & Invasive ductal & $2 \mathrm{~A}$ & T1N1M0 & - & - & - & $\mathrm{UN}$ \\
\hline 43 & 60 & Invasive ductal & $3 \mathrm{~A}$ & T2N2M0 & + & + & - & $\mathrm{UN}$ \\
\hline 44 & 75 & Infiltrative ductal & 4 & T4N0M1 & + & + & + & $\mathrm{UN}$ \\
\hline 45 & 44 & Invasive ductal & $2 \mathrm{~A}$ & T2N0M0 & + & + & - & UN \\
\hline 46 & 69 & Invasive ductal & $3 \mathrm{~B}$ & T4N2M0 & + & + & - & UN \\
\hline 47 & 36 & Invasive ductal & $3 \mathrm{~A}$ & T2N2M0 & - & - & - & $\mathrm{UN}$ \\
\hline 48 & 61 & Invasive ductal & $2 \mathrm{~A}$ & T2N0M0 & - & - & - & UN \\
\hline 49 & 55 & Invasivelobular & $3 \mathrm{~B}$ & T3N3M0 & + & + & - & UN \\
\hline 50 & 60 & Invasive ductal & $2 \mathrm{~B}$ & T2N1M0 & - & - & + & UN \\
\hline 51 & 43 & Infiltrative ductal & 4 & T4N2M1 & + & + & - & $<25$ \\
\hline 52 & 52 & Invasivelobular & $3 \mathrm{~A}$ & T3N1M0 & - & - & + & $<25$ \\
\hline 53 & 51 & Infiltrative ductal & $2 \mathrm{~A}$ & T1N1M0 & + & + & - & $<25$ \\
\hline 54 & 77 & Invasive ductal & $3 \mathrm{~A}$ & T3N1M0 & + & + & - & $\mathrm{UN}$ \\
\hline 55 & 64 & Invasive ductal & $2 \mathrm{~A}$ & T1N1M0 & - & - & - & UN \\
\hline 56 & 59 & Invasive ductal & $3 \mathrm{~B}$ & T4N2M0 & + & - & - & UN \\
\hline 57 & 50 & Invasive ductal & $3 \mathrm{~B}$ & T4N1M0 & + & + & + & 25 \\
\hline 58 & 41 & Invasive ductal & $3 \mathrm{~A}$ & T2N2M0 & + & + & - & $\mathrm{UN}$ \\
\hline 59 & 58 & Invasivelobular & $3 \mathrm{~A}$ & T3N2M0 & + & + & - & UN \\
\hline
\end{tabular}




\section{Continued}

\begin{tabular}{|c|c|c|c|c|c|c|c|c|}
\hline 60 & 54 & Invasive ductal & $3 \mathrm{~B}$ & T4N0M0 & - & - & - & $<25$ \\
\hline 61 & 74 & Invasive ductal & $3 \mathrm{~A}$ & T3N2M0 & + & - & + & $\mathrm{UN}$ \\
\hline 62 & 60 & Invasivelobular & $3 \mathrm{~A}$ & T2N1M0 & + & + & - & 100 \\
\hline 63 & 55 & Invasive ductal & $2 \mathrm{~B}$ & T2N0M0 & + & - & - & $\mathrm{UN}$ \\
\hline 64 & 50 & Invasive intraductal & 4 & $\mathrm{~T} 2 \mathrm{~N} 3 \mathrm{M} 1$ & - & - & + & 25 \\
\hline 65 & 55 & Invasive ductal & $3 \mathrm{~A}$ & $\mathrm{~T} 2 \mathrm{~N} 2 \mathrm{M} 0$ & - & - & - & $\mathrm{UN}$ \\
\hline 66 & 71 & Infiltrative ductal & 3B & T4N2M0 & + & + & - & $\mathrm{UN}$ \\
\hline 67 & 56 & Invasive ductal & $3 \mathrm{~B}$ & T2N3M0 & - & - & - & $\mathrm{UN}$ \\
\hline 68 & 49 & Invasive ductal & 4 & T3N0M1 & + & - & + & UN \\
\hline 69 & 33 & Invasive ductal & $2 \mathrm{~A}$ & T2N0M0 & + & + & - & $\mathrm{UN}$ \\
\hline 70 & 67 & Invasive ductal & $3 \mathrm{~B}$ & T2N3M0 & + & + & - & $\mathrm{UN}$ \\
\hline 71 & 50 & Invasive ductal & $3 \mathrm{~B}$ & T2N1M0 & + & - & - & 50 \\
\hline 72 & 64 & Invasive ductal & $3 \mathrm{~B}$ & T3N3M0 & - & - & + & $<25$ \\
\hline 73 & 68 & Invasive ductal & $3 \mathrm{~A}$ & $\mathrm{~T} 2 \mathrm{~N} 2 \mathrm{M} 0$ & + & + & + & $\mathrm{UN}$ \\
\hline 74 & 63 & Invasive ductal & $3 \mathrm{~B}$ & T3N3M0 & - & - & - & $<25$ \\
\hline 75 & 57 & Invasive ductal & $3 \mathrm{~A}$ & T3N1M0 & + & + & + & $\mathrm{UN}$ \\
\hline 76 & 50 & Invasivelobular & $3 \mathrm{~A}$ & T2N0M0 & + & + & - & 50 \\
\hline 77 & 57 & Invasive ductal & $2 \mathrm{~A}$ & T2N0M0 & - & - & + & $\mathrm{UN}$ \\
\hline 78 & 60 & Invasive ductal & $3 \mathrm{~A}$ & $\mathrm{~T} 2 \mathrm{~N} 2 \mathrm{M} 0$ & + & + & - & $\mathrm{UN}$ \\
\hline 79 & 52 & Invasive ductal & 4 & T2N0M1 & + & - & + & 50 \\
\hline 80 & 58 & Invasive ductal & $3 \mathrm{~A}$ & T2N2M0 & + & + & + & $\mathrm{UN}$ \\
\hline
\end{tabular}

UN: Unmethylated, ER: Estrogen Receptor, PR: Progesteron Receptor.

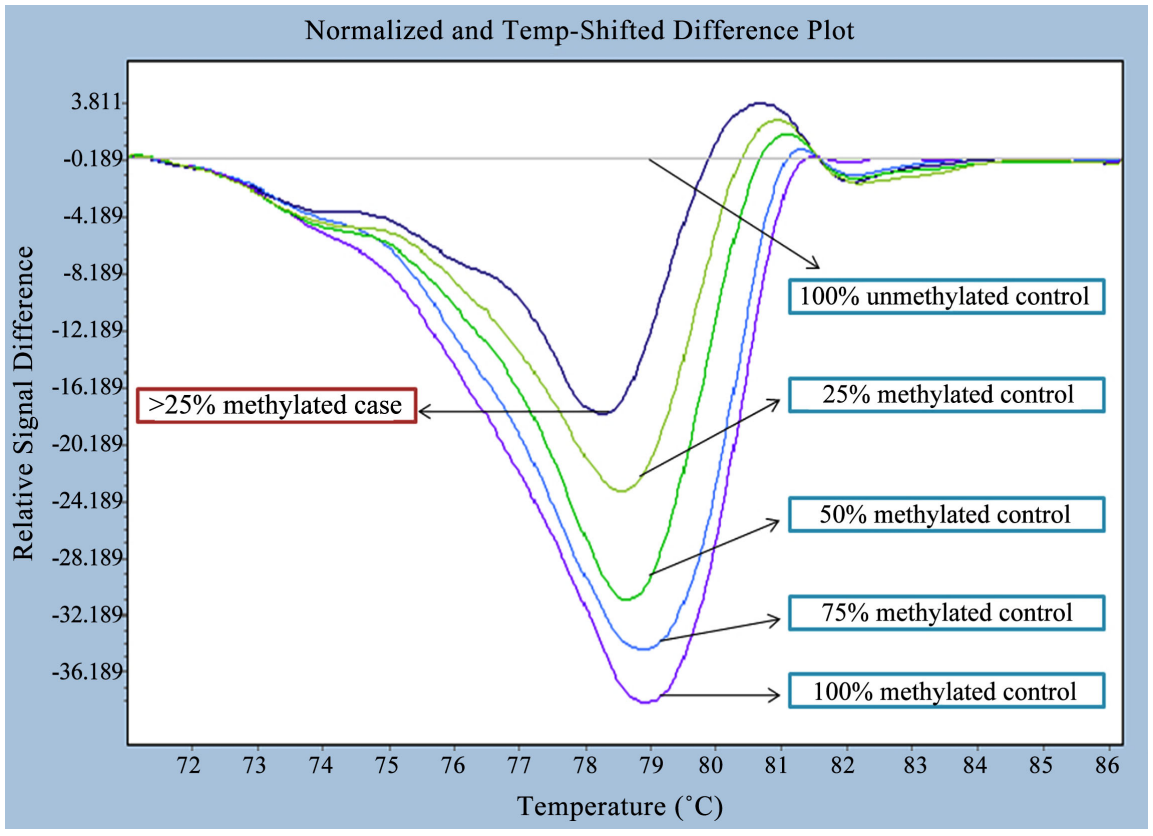

Figure 1. $>25 \%$ of methylated sample seen with the control group in normalized and temperature shifted difference plot by gene scanning. 


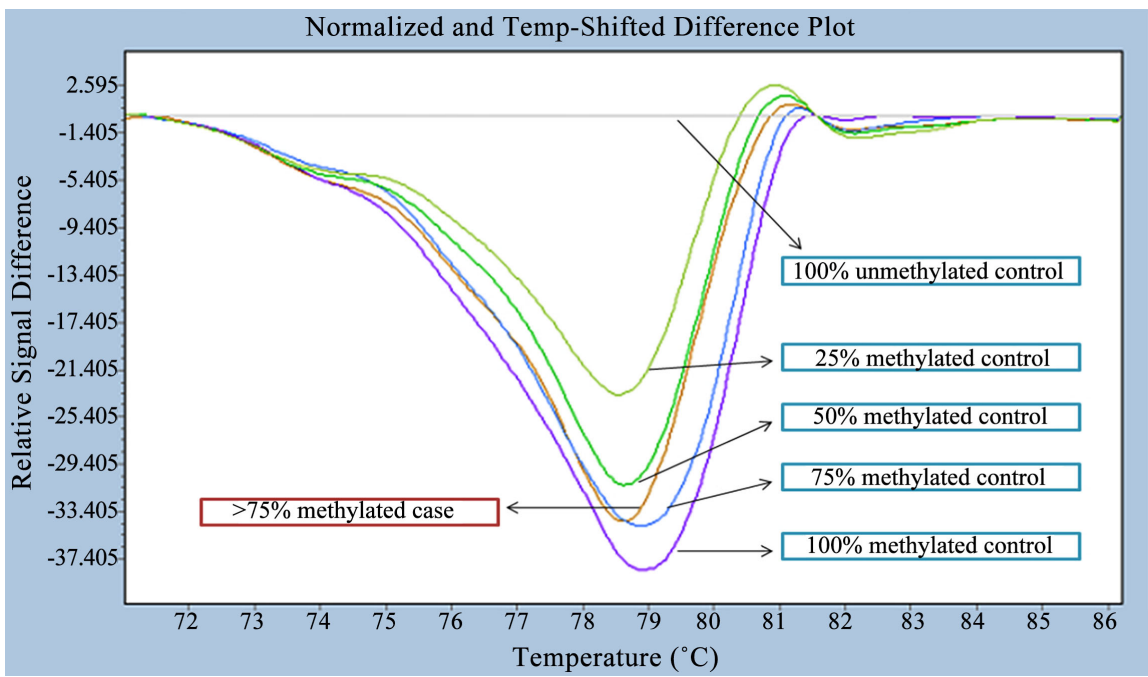

Figure 2. $75 \%$ of methylated sample seen with the control group in normalized and temperature shifted difference plot by gene scanning.

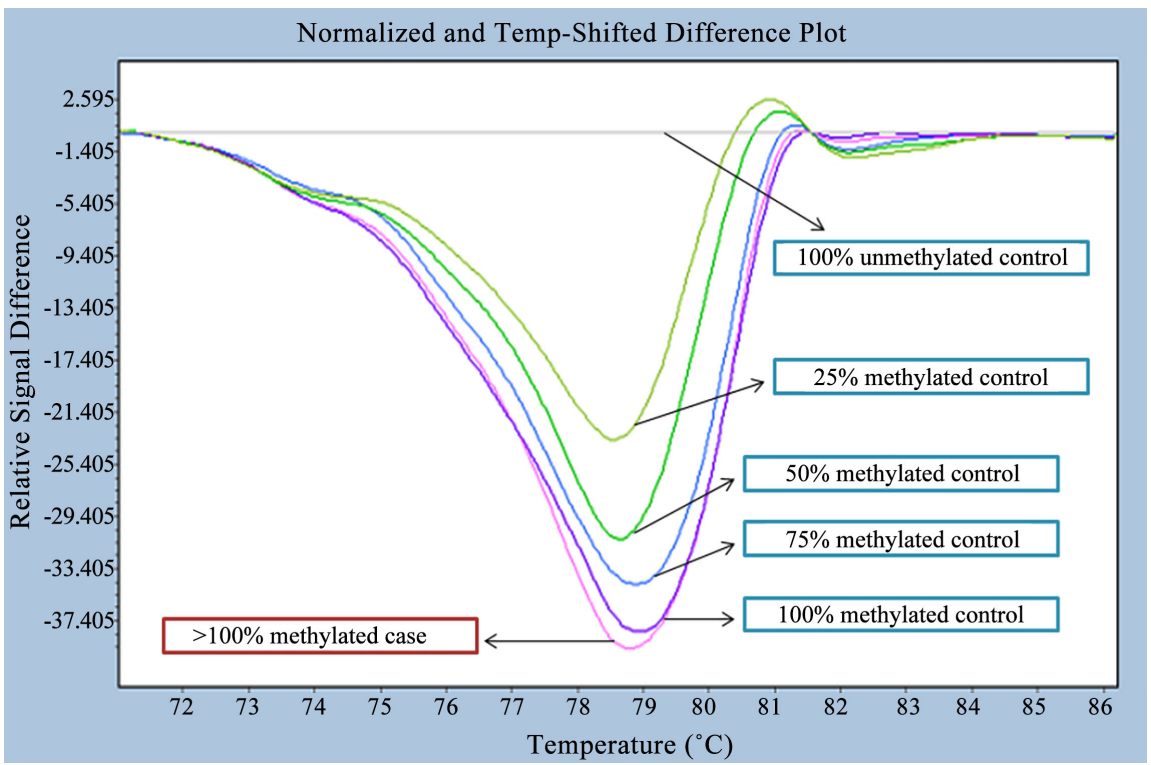

Figure 3. $100 \%$ of methylated sample seen with the control group in normalized and temperature shifted difference plot by gene scanning.

\section{Discussion}

Aberrant promoter DNA methylation has been examined with various methodologies, including COBRA, SSCP, MSP and sequencing [20]. MSP is currently the most widely used method due to its claimed efficiency in heterogeneous cancer cell populations [21]. On the other hand it has limitations since it is time-consuming, more expensive and not quantitative in comparison with MS-HRM [20]. MS-HRM is a novel approach to identify aberrant methylation of gene promoter regions using sequence-dependent melting profiles of each amplicon [22]. It has been considered as the most rapid and sensitive in-tube method capable of detecting even $0.1 \%$ - $1 \%$ of DNA 
methylation in an unmethylated background, minimizing possible sample contamination, and requiring only low amounts of DNA template [20] [23]. Furthermore, MS-HRM is a semi-quantitative method that has been claimed to distinguish homogeneous from heterogeneous methylation [23].

TWIST belongs to the basic-helix-loop-helix family of transcription factors and is implicated in lineage-specific cellular differentiation and survival [24]. TWIST function in vertebrates governs early mesodermal patterning and osteogenesis [25]. Individuals with germ-line haploinsufficiency of the TWIST gene suffer from the hereditary disorder Saethre-Chotzen syndrome (acrocephakosyndactyly type III) characterized by premature craniosynostosis and limb, head, and face anomalies [26]. In cancer development, TWIST functions as a prometastatic oncogene. Expression of TWIST protein counteracts the proapoptotic effects of N-MYC by repression of p19ARF and thereby hampers TP53 function [27].

At the DNA level, cancer development is characterized by genetic and epigenetic events. Methylation of $\mathrm{CpG}$ islands in promoter regions of tumor suppressor genes is a common epigenetic event [28]. Methylation abrogates proper TATA-binding protein binding to the promoter, leading to reduced expression of genes that play important roles in the cell cycle, cell adherence, cell signaling, DNA repair, and apoptosis [29]. Human breast carcinomas exhibit TWIST promoter hypermethylation at high frequency, ranging from $16 \%$ to 77\% [2] [24] [30]. Moreover, methylation of the TWISTpromoter is a good predictor of human breast cancer presence [24]. These findings postulate methylation of the TWISTpromoter as an interesting breast cancer biomarker, but its functional significance remains unknown.

TWIST is a transcription factor that belongs to the basic-helix-loop-helix family and plays important role in cell differentiation and survival [6]. Hundreds of hypermethylated genes have been described in breast cancer. Scanlan et al, found 38\% (37 out of 99) of Twist hypermethylation in breast cancer patients using quantitative multiplex methylation specific PCR (QM-MSP) [31]. In an another study conducted with Twist hypermethylation and type of tumor, they found Twist gene promoter was hypermethylated at a much lower frequency of $16 \%$ (3 of 19) in ILC compared to 56\% (15 of 27) in IDC ( $\mathrm{p}=0.01$ ) [32]. Gort et al. showed that promoter methylation of TWIST is significantly more prevalent in malignant compared to healthy breast tissue (34\%) [9]. Shinozaki et al. showed promoter region CpG hypermethylation was identified in 151 primary breast tumors, TWIST promoter hypermethylation occurs (48\%) [33]. Sunami et al. showed TWIST metyhlation (37.5\%) [34]. Li et al. showed TWIST hypermethylation (59\%) [35]. We found decreased promoter methylation level (25\%). We though that this can be caused by the tumor heterogeneity.

Gort and Shinozaki et al. showed no correlation between clinicopathological parameters with TWIST gene promoter hypermethylation [9] [33]. But Sunami and Li et al. showed methylation status of TWIST gene significantly higher in the ER-positive group [34] [35]. Our study are consistent with the relationship 
between TWIST gene promoter hypermethylation and ER(+) with the Sunami and Li colleagues.

Our results showes increased level than the other researchers caused by the different technique. MSP is non-quantitative and even low amounts of background methylation will not be scored whereas MS-HRM can be used for semi-quantitative estimation of methylation and it's more sensitive and spesifitive than the MSP.

Precision measurement, increasing every 0.1 to 1.0 degrees $\left({ }^{\circ} \mathrm{C}\right)$ caused by the temperature change of fluorescence signal intensity can be factored record refers to. Data retrieval, for every two seconds $0.1^{\circ} \mathrm{C}$ to $1.0^{\circ} \mathrm{C}$ increase in temperature of the fluorescent signal corresponds to is obtained by measuring the change in intensity. This is an indication of DNA denaturation has been a very good track. For this reason, the method is very high specificity and sensitivity. Very low rates of methylation differences can be detected.

\section{Conclusions}

In this study, we have demonstrated a significant association between methylated genes and known histopathological features in breast cancer patients in Turkey. We have shown that DNA methylation can be assessed even small quantities of FFPE DNA. Also MS-HRM is a powerful technique in molecular biology for the detection of epigenetic changes and can be used for semi-quantitative estimation of methylation. MS-HRM also is practically advantageous for use in diagnostics, due to its capacity to be adapted to high throughput screening testing.

Determining the epigenetic changes observed in cancer cells and increasing data related to the issue is gradually becoming important in terms of prevention of cancer, determination of prognosis and development of therapeutic approaches. This situation highlights the importance of methylation as a tumor marker.

Further examination of genes displaying high methylation levels in larger cohorts could provide for the early detection and/or disease monitoring and possibly for influencing therapeutic decisions.

\section{Author Contributions}

O. E. identified cases; prepared samples; performed methylation assays; interpreted data and analyzed data; and wrote the manuscript. O. C. optimazed and performed methylation assays; conceptualized project; provided analysis; wrote and edited the manuscript. S. A. provided project oversight and coordination and analysis; wrote and edited the manuscript. B. D. A. identified cases; interpreted and analyzed data; wrote and edited the manuscript. All authors read and approved the final manuscript.

\section{Acknowledgements}

This work was financially supported by Eskisehir Osmangazi University Research projects (grant number: 201011037) and the study was conducted in 
accordance with the Declaration of Helsinki, and the protocol was approved by the Ethics Committee of Eskisehir Osmangazi University (number: 2010/173). The authors wish to thank Prof. Dr. Serap Isiksoy, Assistant Prof. Dr. Evrim Ciftci and the staff for prepairing formalin-fixed parrafin embeded tissues at Eskisehir Osmangazi University medical faculty of pathology department.

\section{Conflicts of Interest}

The authors declare no conflicts of interest regarding the publication of this paper.

\section{References}

[1] Auwera, I.V., Bovie, C., Svensson, C., Trinh, B.X., Limame, R., Dam, P., Laere, S., Marck, E.A., Dirix, L.Y. and Vermeulen, P.B. (2010) Quantitative Methylation Profiling in Tumor and Matched Morphologically Normal Tissues from Breast Cancer Patients. BMC Cancer, 10, 97. https://doi.org/10.1186/1471-2407-10-97

[2] Bae, Y.K., Brown, A., Garrett, E., Bornman, D., Fackler, M.J., Sukumar, S., Herman, J.G. and Gabrielson, E. (2004) Hypermethylation in Histologically Distinct Classes of Breast Cancer. Clinical Cancer Research, 10, 5998-6005. https://doi.org/10.1158/1078-0432.CCR-04-0667

[3] Bialek, P., Kern, B. and Yang, X. (2004) A Twist Code Determines the Onset of Osteoblast Differentiation. Developmental Cell, 6, 423-435.

https://doi.org/10.1016/S1534-5807(04)00058-9

[4] Candiloro, I.L., Mikeska, T., Hokland, P. and Dobrovic, A. (2008) Rapid Analysis of Heterogeneously Methylated DNA Using Digitalmethylation-Sensitive High Resolution Melting: Application to the CDKN2B (p15) Gene. Epigenetics Chromatin, 1, 7. https://doi.org/10.1186/1756-8935-1-7

[5] Cheol Kim, D., Thorat, M.A., Lee, M.R., Cho, S.H., Vasiljevic, N., Scibio-Bentkowska, D., Wu, K., Ahmad, A.S., Duffy, S., Cuzick, J.M. and Lorincz, A.T. (2012) Quantative DNA Methylation and Recurrence of Breast Cancer: A Study of 30 Candidate Genes. Cancer Biomarkers, 11, 75-88. https://doi.org/10.3233/CBM-2012-0266

[6] Je, E.C., Lca, B.S. and Ga, G.A. (2013) The Role of Transcription Factor TWIST in Cancer Cells. Journal of Genetic Syndromes and Gene Therapy, 4, 124.

[7] Khan, M.A., Chen, H.C., Zhang, D. and Fu, J. (2013) Twist: A Molecular Target in Cancer Therapeutics. Tumor Biology, 34, 2497-2506. https://doi.org/10.1007/s13277-013-1002-x

[8] Mehrotra, J., Vali, M., McVeigh, M., Kominsky, S.L., Fackler, M.J., LahtiDomenici, J., et al. (2004) Very High Frequency of Hypermethylated Genes in Breast Cancer Metastasis to the Bone, Brain, and Lung. Clinical Cancer Research, 10, 3104-3109. https://doi.org/10.1158/1078-0432.CCR-03-0118

[9] Gort, E.H., Suijkerbuijk, K.P., Roothaan, S.M., Raman, V., Vooijs, M., van der Wall, E. and van Diest, P.J. (2008) Methylation of the TWIST1 Promoter, TWIST1 mRNA Levels, and İmmunohistochemical Expression of TWIST1 in Breast Cancer. Cancer Epidemiology Biomarkers \& Prevention, 17, 3325-3330.

[10] Yang, J., Mani, S.A., Donaher, J.L., Ramaswamy, S., Itzykson, R.A., Come, C., et al. (2004) Twist, a Master Regulator of Morphogenesis, Plays an Essential Role in Tumor Metastasis. Cell, 117, 927-939. https://doi.org/10.1016/j.cell.2004.06.006 
[11] Kwon, M.J., Kwon, J.H., Nam, E.S., Shin, H.S., Lee, D.J., Kim, J.H., et al. (2013) TWIST1 Promoter Methylation İs Associated with Prognosis in Tonsillar Squamous Cell Carcinoma. Human Pathology, 44, 1722-1729. https://doi.org/10.1016/j.humpath.2013.03.004

[12] Fu, J., Qin, L., He, T., Qin, J., Hong, J., Wong, J., et al. (2011) The TWIST/Mi2/NuRD Protein Complex and İts Essential Role in Cancer Metastasis. Cell Research, 21, 275-289. https://doi.org/10.1038/cr.2010.118

[13] Ma, L., Teruya-Feldstein, J. and Weinberg, R.A. (2007) Tumour Invasion and Metastasis İnitiated by microRNA-10b in Breast Cancer. Nature, 449, 682-688. https://doi.org/10.1038/nature06174

[14] Vesuna, F., Lisok, A., Kimble, B., Domek, J., Kato, Y., van der Groep, P., et al. (2012) Twist Contributes to Hormone Resistance in Breast Cancer by Downregulating Estrogen Receptor- $\alpha$. Oncogene, 31, 3223-3234. https://doi.org/10.1038/onc.2011.483

[15] Fu, J., Zhang, L., He, T., Xiao, X., Liu, X., Wang, L., et al. (2012) TWIST Represses Estrogen Receptor-Alpha Expression by Recruiting the NuRD Protein Complex in Breast Cancer Cells. International Journal of Biological Sciences, 8, 522-532. https://doi.org/10.7150/ijbs.4164

[16] Widschwendter, M., Siegmund, K.D., Muller, H.M., Fiegl, H., Marth, C., Muller-Holzner, E., Jones, P.A. and Laird, P.W. (2004) Association of Breast Cancer DNA Methylation Profiles with Hormone Receptor Status and Response to Tamoxifen. Cancer Research, 64, 3807-3813. https://doi.org/10.1158/0008-5472.CAN-03-3852

[17] Widschwendter, M. and Jones, P.A. (2002) DNA Methylation and Breast Carcinogenesis. Oncogene, 21, 5462-5682. https://doi.org/10.1038/sj.onc.1205606

[18] Eroglu, O., Baysak, M., Aras, B., Cilingir, O. and Artan, S. (2018) Detection of Promoter Hypermethylation of GSTP1 and CDH1 Genes and the Relationship of Histopathological Parameters of the Breast. Advances in Breast Cancer Research, 7, 91-106. https://doi.org/10.4236/abcr.2018.72006

[19] Esteller, M. (2008) Molecular Origins of Cancer: Epigenetics in Cancer. New England Journal of Medicine, 358, 1148-1159. https://doi.org/10.1056/NEJMra072067

[20] Wojdacz, T.K. and Dobrovic, A. (2007) Methylation-Sensitive High Resolution Melting (MS-HRM): A New Approach For Sensitive Andhigh-Throughput Assessment of Methylation. Nucleic Acids Research, 35, e41. https://doi.org/10.1093/nar/gkm013

[21] Dulaimi, E., Hillinck, J., Ibanez de Caceres, I., Al-Saleem, T. and Cairns, P. (2004) Tumor Suppressor Gene Promoter Hypermethylation in Serum of Breast Cancer Patients. Clinical Cancer Research, 10, 6189-6193. https://doi.org/10.1158/1078-0432.CCR-04-0597

[22] Wojdacz, T.K. and Dobrovic, A. (2009) Melting Curve Assays for DNA Methylation Analysis. Methods in Molecular Biology, 507, 229-240.

https://doi.org/10.1007/978-1-59745-522-0_17

[23] Candiloro, I.L., Mikeska, T. and Dobrovic, A. (2011) Assessing Combined Methylation-Sensitive High Resolution Melting and Pyrosequencing for the Analysis of Heterogeneous DNA Methylation. Epigenetics, 6, 500-507. https://doi.org/10.4161/epi.6.4.14853

[24] Fackler, M.J., McVeigh, M., Mehrotra, J., et al. (2004) Quantitative Multiplex Methylation-Specific PCR Assay for the Detection of Promoterhypermethylation in 
Multiple Genes in Breast Cancer. Cancer Research, 64, 4442-4452. https://doi.org/10.1158/0008-5472.CAN-03-3341

[25] Feng, W., Orlandi, R., Zhao, N., Carcangiu, M.L., Tagliabue, E., Xu, J., Robert Jr., R.C.B. and Yu, Y. (2010) Tumor Suppressor Genes Are Frequently Methylated in Lymph Node Metastases of Breast Cancers Feng. BMC Cancer, 10, 378. https://doi.org/10.1186/1471-2407-10-378

[26] Lee, M.S., Lowe, G.N., Strong, D.D., Wergedal, J.E. and Glackin, C.A. (1999) TWIST: A Basic Helix-Loop-Helix Transcription Factor, Can Regulate the Human Osteogenic Lineage. Journal of Cellular Biochemistry, 75, 566-577. https://doi.org/10.1002/(SICI)1097-4644(19991215)75:4<566::AID-JCB3>3.0.CO;20

[27] Herman, J.G. and Baylin, S.B. (2003) Mechanisms of Disease: Gene Silencing in Cancer in Association with Promoter Hypermethylation.New England Journal of Medicine, 349, 2042-2054. https://doi.org/10.1056/NEJMra023075

[28] Issa, J.P. (2007) DNA Methylation as a Therapeutic Target in Cancer. Clinical Cancer Research, 13, 1634-1637. https://doi.org/10.1158/1078-0432.CCR-06-2076

[29] Maestro, R., Dei Tos, A.P. and Hamamori, Y. (1999) Twist İs a Potential Oncogene That İnhibits Apoptosis. Genes \& Development, 13, 2207-2217. https://doi.org/10.1101/gad.13.17.2207

[30] Suijkerbuijk, K.P., Fackler, M.J., Sukumar, S., et al. (2008) Methylation İs Less Abundant in BRCA1-Associated Compared with Sporadic Breast Cancer. Annals of Oncology, 19, 1870-1874. https://doi.org/10.1093/annonc/mdn409

[31] Swift-Scanlan, T., Vang, R., Blackford, A., Fackler, M.J. and Sukumar, S. (2011) Methylated Genes in Breast Cancer: Associations with Clinical and Histopathological Features in a Familial Breast Cancer Cohort. Cancer Biology \& Therapy, 11, 853-865. https://doi.org/10.4161/cbt.11.10.15177

[32] Fackler, M.J., McVeigh, M., Evron, E., Garrett, E., Mehrotra, J., Polyak, K., Sukumar, S. and Argani, P. (2003) DNA Methylation of RASSF1A,HIN-1, $R A R$-Beta, Cyclin D2 and Twist in in Situ and Invasive Lobular Breast Carcinoma. International Journal of Cancer, 107, 970-975. https://doi.org/10.1002/ijc.11508

[33] Shinozaki, M., Dave, S.B., Hoon, A.E., Giuliano, N.M., Hansen, H.-J., Wang, R. and Bret, T. (2005) Is Associated with Sentinel Lymph Node Metastasis Distinct Hypermethylation Profile of Primary Breast Cancer. ClinCancer Research Clinical Cancer Research, 11, 2156-2162. https://doi.org/10.1158/1078-0432.CCR-04-1810

[34] Sunami, E., Shinozaki, M., Sim, M.S., Nguyen, S.L., Vu, A.T., Giuliano, A.E. and Hoon, D.B.S. (2008) Estrogen Receptor and HER2/Neu Status Affect Epigenetic Differences of Tumor-Related Genes in Primary Breast Tumors. Breast Cancer Research, 10, R46. https://doi.org/10.1186/bcr2098

[35] Li, S.Y., Minna, R. and Barry, I. (2006) DNA Hypermethylation in Breast Cancer and İts Association with Clinicopathological Features. Cancer Letters, 237, 272-280. https://doi.org/10.1016/j.canlet.2005.06.011 


\section{Abbreviations}

ER: Estrogen receptor; F: Forward; FFPE: Formalin-fixed, paraffin-embedded; HER2/neu: Human epidermal growth factor receptor 2; M: Methylation; UM: Unmethylation; MS-HRM: Methylation-sensitive high resolution melting;PCR: Polymerase chain reaction PR: Progesterone receptor; R: Reverse; TWIST: Human basic helix-loop-helix DNA binding protein; WGA: Whole genome amplified. 